\title{
An Investigation into the Use of Amharic Language in English Focus EFL Classrooms: Focus on Teachers Colleges in Amhara Region
}

\author{
Minwuyelet Andualem Desta \\ Lecturer, in Department of English Language and Literature, Debre Tabor University, Ethiopia
}

\begin{abstract}
The main purpose of the study was to examine English focus students and their EFL teachers' use of Amharic language in the EFL classrooms of Amhara region selected Teachers colleges. In this study, a mixed research method involving quantitative and qualitative methods of data collection was employed. The study was conducted on 120 representative students drawn from $1^{\text {st }}, 2^{\text {nd }}$ and $3^{\text {rd }}$ year "English focus ${ }^{\text {se }}$ total student population and $18 \mathrm{EFL}$ teachers of selected teachers training colleges. So as to investigate the use of Amharic language (L1) in EFL classrooms, questionnaires, interviews, and classroom observations were used. The findings of the study revealed that Amharic language was used in all colleges 'English focus' EFL classrooms for various functions at all. The findings also deduced that possible support for the use of Amharic language (L1) in the L2 classroom. Finally, it was recommended that course book writers, syllabus or curriculum designers for the level under study should also make reference to the students' mother tongue wherever appropriate while preparing English language learning, and teaching materials.
\end{abstract}

Keywords: Amharic Language (L1); Foreign Language; Second Language (L2)

DOI: $10.7176 / \mathrm{JLLL} / 63-02$

Publication date: December $31^{\text {st }} 2019$

\section{Introduction}

The controversy over whether English language classrooms should include or exclude students" native language has been a contentious issue for a long time (Brown, 2000). In recent years, researchers have shifted their attention towards exploring the role that L1 plays in L2 classrooms as the issue has become very pressing. Apart from giving the theoretical roles of mother tongue language, some of these (e.g., Choffey, 2001; Deller, 2003) have demonstrated the many ways in which mother tongue language can be used constructively in the L2 classrooms. Harmer (2001; Nun an, Lamb (1996) give useful advice on the importance of the occasional use of studentse first language. Acknowledging the importance of the occasional use mother tongue language, Willis (1981: XIV) on her part indicates that there are times to drop English, for example, to explain the meaning or use of a new word, to explain the aim of the lesson or the next activity, to check studentse understanding after the presentation, and to discuss the main ideas after a reading passage in pairs.

It is possible to learn from the scholars' argument that mother tongue language can have productive pedagogical, affective and socio-cultural roles to play in the L2 classroom. In the Ethiopian Context in general and Amhara region in particular, English is taught as a foreign language. Being a foreign language, the only place learners are expected to have access to the language is in the schools. But, English has long been distanced from being a medium of instruction particularly in schools in Amhara region. This was done without creating an alternative opportunity for students to help them to enhance their English language ability. The situation badly affected the students ${ }^{\text {ee }}$ ability to communicate in English. Because their poor proficiency resulted from limited exposure and other factors. As a result, learners often show need for their L1 use in their English classes even at the colleges' level.

The situation in the Teachers" Colleges in Amhara region, which is the focus of this study, is not different from this one. The teachers" training Colleges which are the focus of this study are a regional colleges located in different towns of Amhara region. The colleges were established to meet the objectives of the (New Education and Training policy of the Federal government of Ethiopia, 1994). The policy also gives regional states the right to establish colleges to train teachers for primary school, second cycle, etc. at diploma level. Besides, the policy gives the regional states the right to decide their respective language of instruction. Consequently, Amharic language is adopted as the instructional language of the training with the exception of English Subjects.

The colleges train teachers and awards Diplomas in teaching different subjects. Amharic, English, Geography, History, Civics, Chemistry, Biology, are some among others. Recently, however, the mode of training has shifted to (ten plus three). It is, thus, difficult to differentiate between Amharic and English Focus students during the first two years of their stay in the colleges as the courses they take are the same. Their differences only begin to emerge in their third year of study when the English Focus students take more English courses. The change in the curriculum also brought about a change in the administrative structure. The English Department is classified under Language stream which heads the two departments (Amharic, and English). It 
does not have its own departments head and authorized activities to run on its own.

The students, like in any other teachers training colleges in Ethiopia, came to the colleges with ESLCE result less than what universities often require. They all speak Amharic language as their first language. Hence, the judicious use of mother tongue language could have socio-cultural, affective and pedagogic roles to play in EFL classrooms. The current study mainly aims at investigating the use of L1 in, English focus EFL class rooms, particularly at Amhara region teachers training colleges.

\subsection{Statement of the Problem}

The issue of learnerse first language (mother tongue language) use in EFL classroom has been a contentious subject among teachers and researchers for centuries. Reading through the research into second language acquisition (SLA), one realizes that the role of learners ${ }^{\text {ee }}$ first language (L1) has been a hotly debated issue. Prodromou (2000) consolidates this view referring to the mother tongue as a „skeleton in the closet. The rationale being that proficiency in English is achieved through exposing learners as much as possible to the target language, learners L1 is mercilessly pushed out of the EFL classroom at all levels during early days of language teaching (Auerbach, 1993). The Teachers "e Colleges' English departments are no exception to this world wide influence. Teachers in the Colleges have long been in dilemma as to the use of the students ${ }^{\text {ee }}$ first language in L2 class room. On the one hand, there has been an English-only philosophy that has been influencing them for years. On the other, they face challenges in the class because the English language teaching philosophy they hold and the classroom reality fall apart.

In the end, however, the researcher is realizing that students find it terribly difficult to understand; a view shared by many colleagues of the researchers themselves. But, with a little use of Amharic language, they began to see many changes in the class. This is firstly because the value of using the mother tongue language in EFL classes is a neglected topic in literature on TEFL methodology. Secondly, there has been the widely advocated principle that the native language should not be used in the foreign language classrooms. This idea of prohibiting first language use increases especially when it comes to the tertiary level.

Moreover, various researches both in Ethiopia and abroad conducted a study on the use L1 in language learning and teaching in different institutions at different levels. As a result, they came up with a variety of recommendations in line with varied problems of the institutions. For example, a research which was conducted by Schweers (1999), Tang (2000), (Taffesse, 1998), Kenenissa, 2003) and the like. Even though studies had been conducted about use of L1 on different aspects at different time in the EFL classes at the primary \& secondary, tertiary level in general, as far as the knowledge of these researcher is concerned, no attempt has been made to further investigate the use of L1 in L2 classrooms on subjects of different background, varying stay in the colleges and a relatively larger sample size even though the continued curriculum revision has created a completely different situation.

Specifically, no study has been carried out at these teachers' Colleges to investigate „English focus ${ }^{\text {ce }}$ students ${ }^{\text {ee }}$ and their teachers' purposes for which they use L1 in L2 classrooms. Besides, the nature of the students L1 need from one year of study to the other has never been considered by any of the researchers so far. Besides to the observed problems, this unquestionable gap highly motivated the researchers to conduct the research on this topic. Thus, the current study will carry out with the intention of fulfilling this gap.

\subsection{Objectives of the Study}

\subsubsection{Main Objective}

The general objective of study is to explore English focus students and their teachers use of Amharic language in their EFL classrooms.

\subsubsection{Specific Objectives}

Specifically, this study strives to

* See whether Amharic language is used by colleges, English focus ${ }^{e e}$ students and their EFL teachers in their EFL classrooms;

* Identify the Purposes for which Amharic language is used in the target classrooms;

\subsection{Research Questions}

Based on the problem stated and the objectives outlined above, the study tried to answer the following research questions:

$>$ Is Amharic language used in the English focus EFL classrooms at the colleges' level?

$>$ What are the purposes for which Amharic Language is used in colleges EFL classrooms?

\section{Materials and Methods}

\subsection{The Research Design}

In this study, descriptive survey research design which applies quantitative and qualitative methods of data 
collection (mixed approach) and analysis will be employed because it is applicable to obtain information about EFL teachers' and the students "e use of first language in their EFL classrooms. Kothari (2004) stated the major purpose of descriptive survey is description of the state of affairs as it exists at present. By the same token, this research set out to describe, and analyze the L1 reality in EFL classes in Amhara region Teachers' Colleges.

And the rationally why mixed approach was employed is that it enabled the researchers to see the issue under study both from qualitative and quantitative perspective. And the nature of the problem and the research objectives invited the researchers to use this research method. Thus, as the study aims at investigating the use of L1 in English focus EFL class rooms, descriptive survey method was used to reveal their practice.

\subsection{Participants}

A research participants were the units of analysis as they are the sources from which research data are being collected (Bless and Higson Smith, 2000). Therefore, data analysis should reflect an accurate picture of the research participants. In light of this, the analysis and the general discussion of this study revolve around students and teachers. The subjects of the study were Amhara region Teachers ${ }^{\text {ee }}$ Colleges' first, second and third year „English focus ${ }^{\text {ee }}$ Students and their EFL teachers.

\subsection{Population and sampling Techniques}

In Ethiopia particularly, in Amhara National regional state, there are ten teachers training colleges. From which, three Teachers ${ }^{\text {ee }}$ colleges (Bege Midir, F/selam and Debre Markos teachers' training colleges) were purposefully selected out of the 10(ten) Amhara region's teachers training colleges. The colleges were purposefully selected because of its ease of accessibility of information for the researchers, and to make the study more manageable and complete within the available time. Also, the researchers have familiarity and acquaintance with the colleges' communities and the colleges' environment so that the problem was closely observed. The English departments were chosen because the researcher believed that most teachers do not expect to encounter this issue among English major students since they were supposedly proficient in English.

Thus, the target populations for the current study were 18 EFL teachers, and 120 sample students of these selected colleges. Since teachers were selected based on the number of the courses offered to the target students at the time of the study, all teachers offering English courses to the selected groups at the time of the study were included. Hence purposive sampling method was employed to select the representative teachers. Secondly, regarding students participations, this study carried out on a randomly selected sample of respondents out of the total populations. Gay and Airasian (2003) pointed out that, in a study the sample size should be selected 10$20 \%$ of the total populations. Thus, Out of the total colleges English major students, 10\% of students were selected equally through random sampling technique (Lottery method).

\subsection{Data Collection Instruments}

The instruments used to collect data for the study were interviews, questionnaires, and classroom observation. These instruments were selected because of their suitability for gathering important data for the study. Each of these instruments is briefly described below.

\subsubsection{Interview}

Unstructured interview is one important research tool employed in order to get in-depth information from the respondents. It is this type of interview the researchers attempt to achieve a holistic understanding of the interviewees' point of view or situation (Dawson, 2002). In the study, interview used as other data collection tool and was designed to collect relevant data from the colleges EFL teachers. To the current study, unstructured interviews was conducted by the researcher for teachers who are offering courses to the subject of the study at the time. Because, unstructured interviews is more flexible to collect the data for the current study as needed.

\subsubsection{Questionnaire}

The questionnaire helps to collect a great deal of information within the time limit and help to reach large group of research subjects (Kothari, 2004). The questionnaire was one of the major data gathering tools employed for securing pertinent information for the study. Because it enabled the researcher to collect data from large group of individuals within a short period of time. In the current study, to get additional information to the data obtained from the teachers through the interviews, questionnaires will be used as data collection instruments and designed to collect relevant data from the sample teachers and students of the teachers training colleges. The questionnaire was prepared for both students and teachers to address the variables of the study by providing information that conformed to the research questions.

\subsubsection{Observation}

As to Kumar (1996), observations are important tool that can be employed in descriptive research and other qualitative research types for gathering genuine and pertinent data on teachers' and students' behaviors in the actual setting. According to Best and Khan (1989), observation gives the firsthand account of situation under study, and combined with other data collecting tools, it allows for holistic interpretation of the situation which is 
being studied.

In the current study, the researcher used this data gathering tool as supplementary instrument to collect the available information for the study. Thus, the researcher used structured observation method to observe the teachers "e classes at least once to check/ to triangulate whether what the teachers' and students' responses to the questionnaires and interview questions match what they actually do in the EFL classes.

\subsection{Data Collection Procedure}

In the course of collecting data for the current study, all the necessary procedures were followed.

First, the researchers asked permission from the concerned bodies and explain the purpose of the study before conducting those instruments. Since, this enabled the researcher to collect the data effectively, and exploit full information from the target respondents freely within the colleges. Accordingly, after getting permission from the concerned bodies, the researchers observed EFL teachers' classes at least once times each at the different time. Then after holding the teachers' class room observations, the questionnaires were distributed for sample teachers, and students of the colleges. Finally, next to the teachers', and students', questionnaires, the interview was held for colleges EFL teachers regarding L1 use in English focus EFL classes.

\subsection{Methods of Data Analysis}

Data analysis requires the researchers to be comfortable with developing categories and making comparisons and contrasts. For the current study, the researcher employed mixed method (data which were analyzed through both quantitative \& qualitative methods) to see the issue under study both from quantitative and qualitative perspective. Quantitative research method helps to analyze a data which was quantitative in nature, whereas qualitative research method is used to analyze those data which were not quantitative in nature (Kumar, 2006).

The responses of close ended items of the questionnaires were tabulated, analyzed, and described quantitatively through using several sets of statistical analyses like, percentage, and mean values. Since, these statistical tools are important for this study because they provide information about the average participants score on a measure. However, the analysis of the data which were collected using the interview, and observation items were analyzed using qualitative method of data analysis through using narrative form and in an interpretive manner.

\section{Results and Discussions}

\subsection{Introduction}

This chapter deals with the analysis and discussion of the data collected from subjects to seek answers for the basic research questions raised in the statement of the problem. The primary purpose of this study was to explore „English focus ${ }^{\text {ee }}$ students and their teachers use of Amharic language in their EFL classrooms or not (i.e. issues related to whether Amharic language is being used in colleges English Focus EFL classrooms or not, and the purposes for which teachers and students use Amharic language in EFL classrooms) were treated. Accordingly, 120 English major students responded to the questionnaires and the 18 EFL teachers responded to the questionnaire, and interviews, and classroom observation as a sample were assumed to be adequate for the analysis. The analysis was made in terms of the basic research questions raised in the first chapter of the study.

\subsubsection{Results of the Study}

\subsection{Issues related to whether Amharic language is present in EFL classroom or not.}

The three items provided above were designed with the aim of investigating whether Amharic language is used in colleges EFL classrooms or not. To arrive at a sound conclusion regarding the issue; the items were sought to investigate, percentages, and the mean scores of the responses of the groups were calculated for the three items.

Table 1. Students' responses to the issue related to whether Amharic language is present in L2 class room or not

\begin{tabular}{|c|c|c|c|}
\hline List of Items & $1^{\text {st }}$ Year & $2^{\text {nd }}$ Year & $3^{\text {rd }}$ Year \\
\hline & $\%$ & $\%$ & $\%$ \\
\hline 1. I use Amharic language in my English class rooms & 4436.74 .56 & 4537.54 .51 & 3125.84 .34 \\
\hline 2. My roommates use Amharic language in their EFL classes & $44 \quad 36.74 .47$ & 4537.53 .54 & 3125.84 .6 \\
\hline $\begin{array}{l}\text { 3. My EFL teachers use Amharic language in their EFL } \\
\text { classes }\end{array}$ & $44 \quad 36.74 .38$ & 4537.54 .42 & 3125.54 .44 \\
\hline
\end{tabular}

$\mathrm{F}=$ Frequency; $\%=$ Percentage; $\mathrm{M}=$ mean

As it has been indicated in the above table, the percentage, and mean scores for the first item are, \%= 44(36.7), $\mathrm{M}=4.51, \%=45(37.5) \mathrm{M}=4.56$, and $\%=31(25.8), \mathrm{M}=4.34$ for first, second and third years respectively. Similarly, the percentage, and mean scores of the second item in the groups are $\%=44(36.7), M=4.47, \%=$ 45(37.5), $M=3.54$, and $\%=31(25.8), M=4.6$ for first, second and third years respectively while the mean scores for the third item is $\mathrm{M}=4.38, \%=44(36.7), \mathrm{M}=4.42, \%=45(37.5)$ and $\mathrm{M}=4.44, \%=31(25.8)$ for the three respective groups.

The implication is that Amharic language is widely used by students in EFL classroom. This is because 
each of the mean scores of the three items was well beyond the assumed mean (3) with a narrow degree of variability of the individual scores from the mean scores of the group. The responses cumulative mean scores indicate that students agreed to the points raised all colleges. These tell us that the majority of the students reacted to the items positively and would like to use Amharic language in their EFL classrooms. The students not only witnessed their Amharic language use in the EFL classrooms but also unreservedly pointed out their EFL teachers ${ }^{e e}$ use of Amharic language in their EFL classrooms. What would teachers those who were teaching in all colleges say?

Table 2. Teachers' responses to the issue related to whether Amharic language is present in L2 classrooms.

\begin{tabular}{l|lll|} 
No List of Items & F & $\%$ & M \\
\cline { 2 - 5 } 1. I use Amharic language in my English lesson & 18 & 100 & 4.43 \\
2. My colloquies use Amharic language in their EFL lesson & 18 & ", & 4.43 \\
3. My students use Amharic language in their EFL class rooms & 18 & ", & 4.43
\end{tabular}

$\mathrm{F}=$ Frequency; $\%=$ Percent; $\mathrm{M}=$ mean

As it can be observed from the above table, teachers from all colleges reacted to the items destined for assessing the presence of Amharic language (L1) in L2 classrooms in a positive manner. The items were designed to take the account of whether teachers use Amharic language in their colleges EFL classrooms. The obtained result was that teachers strongly showed their support for Amharic language use in EFL classrooms. Teachers admitted that they use Amharic language in EFL lessons. They also confirmed that their colleagues and their „English focus ${ }^{\text {ee }}$ students use Amharic language (L1) in their EFL classrooms with means similar to that of item one.

In general terms, teachers like students confirmed the presence of L1 in their EFL classrooms and that they were engaged in its use. As one can clearly see from the above table, all the mean scores for the items were more than 4.0 which is an indication that the respondents nearly strongly agree to the concepts. This is said because all the mean scores of the descriptors of the Amharic language (L1) presence issue were found to show students ${ }^{\text {ee }}$ high agreement to the proposed statements. Thus, teachers also accept that L1 is playing some role in their EFL classrooms. All in all, it seems that teachers and students declare that their L1 use in EFL classrooms without any reservation. Both teachers and students uniformly witnessed the presence of Amharic language in their EFL classrooms. The unequivocal statement made by students and teachers about the fact that they were engaged in its use reflects that Amharic language (L1) is widely used in EFL classrooms at the colleges level and hence present.

\subsection{Purposes for which students and Teachers want to use Amharic language in EFL Classrooms}

The following table revealed that the data obtained in response to items one-eight from first, second and third year colleges students. The items were designed to seek information from the students on the purposes for which they use Amharic language in their EFL classrooms. Concerning to the case for other preceding responses, it was also worth considering the degree of variability of the scores or the extent to which the scores are dispersed around the average figure. The percentage, and means scores were calculated for responses of the students in an attempt to investigate the real purposes for which Amharic language is used in EFL classrooms.

Accordingly, the percentage, and mean scores of the responses to items 1, 2, and 3 for first year students are $\%=44(36.7), M=4.03, \%=45(37.5), M=4.02$, and $\%=31(25.8), M=4.2$ respectively. For second year students, percentage, and the mean scores of the items 1,2 , and 3 are $\%=44(36.7), M=4.23, \%=45(37.5), M=$ 4.56 , and $\%=31(25.8), M=4.53$ respectively. These items received a similar result from third year students as their percentage, and mean is $\%=44(36.7), M=3.40, \%=45(37.5), M=4.23, \%=31(25.8), M=4.01$ for items 1,2 , and 3 respectively. Each of the mean scores of the items discussed above was found to be above (4) which symbolizes students ${ }^{\text {ee }}$ agreement to the proposed statement.

The implication is that students, through first to third year would like to use Amharic language to exchange information with others in pair and/ or group work. Nevertheless, views in literature with regard to the use of L1 in Pair and/ or group work are very contradicting though students expressed that they use it. Some (e.g., Cook 2001a, b; Atkinson 1987) favor it with the belief that code switching is a normal phenomenon through which students can help each other in the L2 classroom.

Research findings (e.g., Anton and Di Camilla 1998) on the other hand, indicate that using L1 in pair or group work provides students with scaffold help. In my opinion, as many of the scholars (e.g., Cook 2001a,b; Harmer 2001) believe; since the students ${ }^{\text {ee }}$ use of L1 in pair/group work is inevitable, it would be better to give them advice on when to use and when not to rather than trying to prohibit it. Again, students claimed that they need L1 to learn the meanings of new English words.

Here, Schweers (1999), on his study noted that the use of the mother tongue in English classes, concludes that ,a second language can be learned through raising awareness to the similarities and differences between the 
L1 and L2e. (Cole, 1998), if students have little or no knowledge of the target language, L1 can be used to introduce the major differences between L1 and L2, and the main grammatical characteristics of L2 that they should be aware of this issue at all.

Table 3. Purposes for which students use Amharic language (L1)

\begin{tabular}{|c|c|c|c|c|c|}
\hline \multirow[t]{2}{*}{ No $\quad$ List of Items } & \multicolumn{2}{|l|}{$1^{\text {st }}$ Year } & $2^{\text {nd }}$ Year & \multicolumn{2}{|l|}{$3^{\text {rd }}$ Year } \\
\hline & & & F \% & F $\%$ & \\
\hline 1. I use Amharic language in pairs/groups & $44 \quad 36.7$ & 4.03 & 4537.54 .02 & 3125.8 & 4.2 \\
\hline 2. I need Amharic language to learn new English words & 4436.7 & 4.23 & 4537.54 .56 & 3125.8 & 4.53 \\
\hline $\begin{array}{l}\text { 3. I want EFL teachers to use my L1 to explain grammar } \\
\text { concepts }\end{array}$ & 4436.7 & & 4537.54 .23 & 3125.8 & 4.01 \\
\hline 4. Complex instructions should be given in L1 & 4436.7 & 2.54 & 4537.51 .05 & 3125.8 & 4.02 \\
\hline 5. I want EFL teachers to use L1 to & 4436.7 & 2.20 & 4537.51 .27 & 3125.8 & 2.16 \\
\hline 6. I want EFL teachers to use L1 to & 4436.7 & 3.88 & 4537.54 .08 & 3125.8 & 4.20 \\
\hline 7. I want EFL teachers to use L1 to elicit language & 4436.7 & 2.11 & 4537.51 .08 & 3125.8 & 1.06 \\
\hline 8. I want EFL teachers to show differences $\mathrm{b} / \mathrm{n}$ L1 \& L2 & 4436.7 & 3.58 & 4537.51 .09 & 3125.8 & 1.21 \\
\hline
\end{tabular}

$\mathrm{F}=$ Frequency; $\%=$ Percent; $\mathrm{M}=$ mean

Besides, students indicated that they want their teachers to use L1 sometimes when explaining grammar concepts. There was no disparity among the groups as far as reflecting their high need for L1 is concerned. Put differently, the groups ${ }^{\text {ee }}$ responses were in agreement with regard to the item that stipulates whether they want the grammar concepts to be explained for them in L1 occasionally. Similarly, students demanded Amharic language use while explaining the differences between Amharic language and English Grammar. Schweers (1999), in a report of the outcomes of his research on the use of the mother tongue in English classes, concludes that ,a second language can be learned through raising awareness to the similarities and differences between the L1 and L2 ${ }^{\text {ee }}$ (Cole, 1998), if students have little or no knowledge of the target language, L1 can be used to introduce the major differences between L1 and L2, and the main grammatical characteristics of L2 that they should be aware of.

This gives them a head start and saves a lot of guessing. As suggested by Cole et al. in Japanese context study, he concluded that students can benefit from appropriate teachers use of L1, especially in order to explain new words, explain grammar, and to facilitate explanation of complex instructions. (Critchley, 1999) also reported that the situations where $\mathrm{L}^{\mathrm{ee}} \mathrm{s}$ use was desirable were specified as when students couldn't understand, and when learning difficult words or grammar. Students showed high interest for the mentioned purposes in this study too.

The items disfavored by the students in all samples of the study were items 4, 5 and 7 . All through the first to third year, the mean scores for these items were below the expected mean value. This means that students neither wanted to have EFL classrooms instructions in Amharic language nor did they want their teachers to use Amharic language to check comprehension. Again they didn't show agreement with the teachers ${ }^{\text {ee }}$ use of first language to elicit language. So, students felt that L1 use was inappropriate on these three occasions. With the exception of these, the other items received a warm hug from the majority of the students in the study groups. With regard to giving complex instruction, which students denied having in L1 altogether, the teachers ${ }^{\text {e }}$ questionnaire, interviews and classroom observation report surprisingly different results from the students ${ }^{\text {ee }}$ questionnaire data?

The mean scores of the responses of this item in the groups are all far below the expected mean implying that students are not in favor of L2 instructions being given in L1. Yet, the teachers ${ }^{\text {ee }}$ questionnaire data and interview specifically stressed the importance of highlighting L2 classroom instructions in L1. Similarly, the classroom observation also revealed that students were unable to understand what to do when instruction was given exclusively in English. Even though students discouraged its use in L2 classrooms, the classrooms reality seem to dictate the use of L1 to brief the L2 complex classrooms instructions. Concerning to Harbored (1992), who reported that the biggest reason for using L1 in the L2 classroom is that it can save a lot of time and avoid confusion. Again, teachers assured the researcher that they use L1 when they teach culture related issues. Also, why teachers argue that, they were involved in its use was that there are concepts which are better explained using L1 than L2. In general, teachers said they use L1 in their classrooms to help their students learn better and be confused. 
Table 4. Purposes for which teachers use Amharic language (L1)

\section{No List of Items}

1. Amharic language is important in EFL in pairs/groups

2. I want L1 to teach new English words

3. I sometimes use L1 to explain new grammar concepts

4. I give complex instructions in Amharic language

5. I use Amharic language to check comprehensions

6. I use Amharic language to explain difficulties

7. I use Amharic language to elicit English language

8. I use Amharic language to show differences $\mathrm{b} / \mathrm{n} \mathrm{L} 1 \& \mathrm{~L} 2$

$\mathrm{F}=$ Frequency, $\%=$ percentage, $\mathrm{M}=$ mean

The above data indicated that the percentage, and mean scores for all items given to teachers to check the purposes for which they use Amharic language in their EL teaching were found to be above the ideal mean implying that teachers use Amharic language for all classrooms purposes they were asked to respond to. Even though the mean scores for the items questioned were all above the expected mean value, the scores for some (items 2, 5, and 7) seem to be closer to three making the conclusion drawn less confident. However, for items 1 , $3,4,6$, and 8 the mean scores were well above the benchmark. No matter what, teachers confirmed that they use first language for all the mentioned purposes in EFL classrooms at all colleges' level.

In addition to the questionnaire data, more purposes for which the teachers use L1 were explored through interview. During interview, teachers said that they use L1 for purposes like localizing activities and introducing culture related issues other than the ones mentioned in the questionnaire. Owing to his research report, (Schweers, 1999) also went as far as saying the use of L1 in the classroom is necessary. According to the interviewee, using L1 in their classrooms paves the way for healthy classrooms interaction based on mutual understanding which thereby facilitates L2 learning.

Teachers and students were in some cases in agreement about when L1 should be used or when a teacher should use L1. Both teachers and students believed that L1 is important in pairs and/or group works and helps a lot to teach new vocabulary, explain grammar concepts, show difficult concepts and to explain the differences between L1 and L2. To the contrary, teachers and students differed in their suggestions of some of the occasions when L1 should be used. Students do not want teachers to use first language to give classrooms instructions, elicit language and to check comprehension. Yet, the teachers believe that first language should be used for these purposes contrary to the students as well. For instance, teachers felt that L1 should be used to give classrooms instruction, elicit language and check comprehension. The interviewees also pointed that there are times when they themselves run out of words/expressions to explain some concepts. Burden (2001) came up with a similar report in a Japanese university context where he observed the studentse purposes for using L1 contravening teachers"e purposes on some occasions. With regard to item three which was designed to seek information on the problems that teachers and students encounter in relation with the exclusive use of English, teachers gave broad and complementing accounts.

\subsection{Discussions}

The main purpose of this study was to investigate students and their teachers use of L1 in their EFL class rooms. In reaction to the research questions seeking their response on whether they argue for or against the common criticism that L1 reduces learnerse ${ }^{\text {ee } 2 ~ e x p o s u r e, ~ t h e y ~ w e r e ~ a l l ~ f o u n d ~ t o ~ r e f u t e ~ t h e ~ c r i t i c i s m ~ a s c r i b i n g ~ t o ~ m a n y ~}$ practical realities they knew in their EFL classrooms. It would have been a preference for them all to use only English in English classroom had the practical classroom reality been encouraging. The results from the analysis of data from interview, questionnaire, and observations are discussed in line with some empirical findings.

1. The first research question was examining whether Amharic language is used by colleges, English focusee students and their EFL teachers in their EFL classrooms. This question was designed to assess the teachers and students use of Amharic language in English focus English foreign language class rooms.

As mentioned earlier, the first issue that the researcher investigated was issues related with whether Amharic language is used in English language class rooms or not. Here, teachers seem to be convinced by the classroom reality that learners ${ }^{e c}$ first language should be used in EFL classes, they feel uneasy about using it, permitting its use in the classroom or talking about the fact that they use in the class. Both teachers and students uniformly witnessed the presence of Amharic language in their EFL classrooms. The unequivocal statement made by students and teachers about the fact that they were engaged in its use reflects that Amharic language (L1) is widely used in EFL classrooms at the colleges level and hence present. These tell us that the majority of the students reacted to the items positively and would like to use Amharic language in their EFL classrooms.

The students not only witnessed their Amharic language use in the EFL classrooms but also unreservedly pointed out their EFL teachers ${ }^{\text {ee }}$ use of Amharic language in their EFL classrooms. As the results of the study 
revealed, that teachers like students confirmed the presence of L1 in their EFL classrooms and that they were engaged in its use. As one can clearly see from the data analysis, all the mean scores for the items were more than the expected mean values which is an indication that the respondents nearly strongly agree to the concepts. This is said because all the mean scores of the descriptors of the Amharic language (L1) presence issue were found to show students ${ }^{\text {ee }}$ high agreement to the proposed statements.

Thus, teachers also accept that L1 is playing some role in their EFL classrooms. The finding of this study tends to consistent with the findings of Prodromou (2000) consolidates this view referring to the mother tongue as a ,skeleton in the closet. The rationale being that proficiency in English is achieved through exposing learners as much as possible to the target language, learners L1 is mercilessly pushed out of the EFL classroom at all levels during early days of language teaching (Kenenisa, 2003). As the results of the data gathered from both the questionnaire and interview illustrates that all most all of the teachers training colleges' students and their teachers use Amharic language in their EFL class rooms. This reveals that there is the dominance of the L1 in L2 class rooms of teachers training colleges at all.

2. The second research question was proposed to explore the purposes for which students and their EFL teachers use Amharic language in the EFL class rooms. In line with this, the obtained result was that teachers strongly showed their support for Amharic language use in EFL classrooms. Teachers admitted that they use Amharic language in EFL lessons. They also confirmed that their colleagues and their „English focus ${ }^{\text {ee }}$ students use Amharic language (L1) in their EFL classrooms with means similar to that of item one.

Teachers said students do not understand the concept of an English exclusive lesson because of their poor English proficiency resulted from lack of adequate exposure. If they don't understand, they lose interest and become passive. What's more, they would be discouraged to explore further. Most of the problems were corporate/consistent with what (Burden, 2000) points that increasing the amount of L2 instead of perhaps a simple explanation in L1 is likely to have a negative effect and simply add to the frustration on the students part. Almost all the teachers interviewed stressed the importance of making the complex instructions clear using L1 as they thought this was the key to unlocking the door that paves the way to classroom interaction. This finding agrees with what Critchley (1999) finding revealed as $80 \%$ of the English language teachers and their students use Amharic language for various purposes in the English focus EFL class rooms. The findings of this study consistent with what Schweers (1999) noted that most cite the following as instances when they find L1 use the most useful: to explain difficult concepts; when they feel lost; to feel more comfortable and confident; to check comprehension; to define new vocabulary items and the like.

\section{Conclusions}

As it has already be mentioned earlier, the main purpose of this study was to investigate the classroom use of first language in Colleges „English focuse EFL classrooms of different levels. Consequently, the study was guided by research questions that the researcher wanted to be answered at the end. Hence, the first question was about whether Amharic language is used in Colleges target groups ${ }^{\text {ee }}$ EFL classrooms or not. Secondly, the purposes for which teachers and students use of L1 in the EFL class rooms. To this end, the study devised mechanisms that would enable it to dig out what it was set out to unveil.

To begin with, the findings of this study indicated that first language is not only present in colleges „English

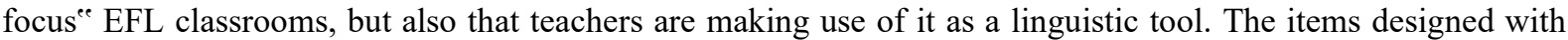
the intention of investigating this fact came up from all the study groups with a positive result that reveals the presence of L1 in colleges EFL classrooms. Both teachers and students agree that using L1 is important for functions like in pair and/or group work, to explain grammar concepts, to teach/learn the meanings of new English words, to explain difficult concepts, and to see differences between L1 and L2.

As far as the classroom instruction was concerned, the tools produced conflicting results. Teachers, both in the questionnaire they completed and interview, strictly stressed the importance of highlighting EFL classrooms instructions in Amharic language ascribing to the students poor comprehending ability while the data obtained from the students was in contradiction with this view. The observation data was used as a reconciling tip. Students, especially those in their second and third year of study, couldn't understand complex instructions given by teachers during the class times they were visited even though they were respondent enough to the simple and commonly used instructions. Consequently, the observation result validated the teachers claim. Teachers might take this into account when using first language.

\section{Acknowledgements}

In conducting this study, the researcher used both financial and human resources. Due to the fact that, and first of all, I would like to express my deep gratitude to Debre Tabor university for its assistance in the way of covering the cost needed for the study at all. Next, I would like to give great thanks for all participants who cooperate with me in the data collection process of the study. 


\section{References}

Auer Bach, E. (1993). Reexamining English Only in the ESL Classroom, TESOL Quarterly, 27(1), pp.9-32

Brown, H. (2000). Principles of Language Learning and Teaching. Longman: San Francisco.

Brown, J. D. (2001). Using Surveys in Language Programs. Cambridge University Press

Burden, P. (2000). The use of the students" mother tongue in monolingual English "Conversation" classes at Japanese universities, The Language Teacher Online, 24(6).

Coffey, S.2001. The L1 Culture in the L2 Classroom, Modern English Teacher, 10(2), pp.54- 58.

Chomsky, N. (1976). Reflection on Language. London: Temple Smith.

Cole, S. (1998). The Use of L1 in Communicative English Classrooms, The Language Teacher JALT Journal, on-line internet. Available: http. //www. JAL Publications. Org/tilt/files /98/Dec/Cole. Html

Cohen, L. (2000). Research methods in education. Rutledge Flamer 29 West 35th Street, New York, NY 10001. $5^{\text {th }} \mathrm{Ed}$.

Cook, G. (2002). Breaking Taboos, English Teaching Professional, Issue23, pp.5-7.

Cook, V. (1999). Creating Second Language Users. On-line internet. Available: http://private www.essex.ac.uk/ Cook/OB519.htm.

Critchley,M. (1999). Bilingual support in English classes in Japan: A survey of student opinions of L1-use by foreign teachers. The language teacher, 23(9), 19-13.

Deller, S. (2003). The Language of the Learner, English Teaching Professional, Issue 26, pp.5 7.

Duff, A. (1989). Translation. Oxford: Oxford University Press

Frankenberg-Garcia, A. (2000). Using Portuguese in the Teaching of English. On- line internet.

Available: http://www. Portuguese mct.pt/ Repository/ Frankenberg-Garcia 2000b.doc.

Gabielatos,C.(2001). L1 Use in ELT: Not a Skeleton but a Bone of Contention. Com /nil /70/700/.html.

Gay I.R. and Airasian (2003). Educational Research: Competencies for Analysis and Application. $7^{\text {th }}$ edition .New Jersey: Merrill Prentice Hall.

Green, J. F. (1970). The Use of the Mother Tongue and the Teaching of Translation. ELT Journal, 24: 217-223.

Harmer, J. (2001). The Practice of English Language Teaching. Edinburgh Gate: Pearson Education Ltd.

Kenenisa, B. (2003). Using L1 in the EFL classroom: The case of the Oromo language with particular reference to Adama Teachers College. AAU, unpublished MA thesis.

Krashen, S. (1981). Second Language Acquisition and Second Language Learning. Oxford: Pergamum.

Langer, S.L. (2001). The Effect of Home Language Use in the ESL Classroom: Additive or Subtractive? On-line internet. Available: A:/the effect of home language use in the ESL classroom.5-langer.htm

Linder, D. (2002). Translation, English Teaching Professional, Issue 23, pp39-41

Miles, R. (2004). Evaluating the Use of L1 in the English language Classroom. School of Humanities. Centre for English Language Studies Department of English. University of Birmingham

Ministry of Education. (1997). English for Ethiopia: Grade Eleven - Teacher's Book I. Addis Ababa: EMPDA.

Mitchell, R. (1988). Communicative Language Teaching: in Practice. CILT: London

Nunan,D. and Lamb,C. (1996). The Self-Directed Teacher. Cambridge: Cambridge University Press.

Polio, C. (1994). Comment on Else Roberts Auerbach"s "Reexamining English only in the ESL classroom. TESOL Quarterly, 28 (2):153-161

Prodromou, L. (2001). From Mother Tongue to Other Tongue, On-line internet. Available: http//www. Tesolgreece.com/mother.html

Richards, J. C. and Rodgers, T. S. (2001). Approaches and Methods in Language Teaching. 2nded. Cambridge: Cambridge University Press

Rubin, J.1975. What the Good Language Learners can Teach Us, TESOL Quarterly. 9(1), pp.41-51

Schweers, C.W. (1999). Using L1 in the L2 Classroom, English Teaching Forum, 37(2), pp. 6-13 